\title{
The Practice of Critique: A Comment on Fassin
}

\author{
Tania Murray Li
}

Version Post-print/accepted manuscript

Citation Murray Li, T. (2017). The Practice of Critique: A Comment on Fassin. (published version) Anthropological Theory, 17(2), 262-264.

Doi: $\underline{10.1177 / 1463499617716834}$

Publisher's Statement Copyright (C) 2016 Tania Murray Li. Reprinted by permission of SAGE Publications.

How to cite TSpace items

Always cite the published version, so the author(s) will receive recognition through services that track citation counts, e.g. Scopus. If you need to cite the page number of the author manuscript from TSpace because you cannot access the published version, then cite the TSpace version in addition to the published version using the permanent URI (handle) found on the record page.

This article was made openly accessible by $U$ of $T$ Faculty. Please tell us how this access benefits you. Your story matters. 


\section{The Practice of Critique: A Comment on Fassin}

Building on Didier Fassin's astute and timely paper, I propose to reflect on the practice of critique by considering its beginnings, its mediations, and the ends to which it is deployed. I also consider the role of ethnographers in advancing critical practices.

Beginnings: Fassin notes the derivation of critique from the ancient Greek verb krinein, "to separate, to distinguish;" also to discern, select, decide, or pass judgement. ${ }^{1}$ Dwelling on the verb highlights the distributed character of critique as practice: we all experience separation - a sense of unease, of not being "at one" with the world around us; we all have the capacity to make distinctions; and we all pass judgements. By detaching the practice of critique from authority, and from the critic as a particular kind of person (a person authorized to pass judgement), a broad terrain of ethnographic inquiry opens up. If everyone is a critic, and the world is full of critical practices, which critical practices do ethnographers elect to explore?

We could focus on social movements and mobilized groups whose practices of critique are explicit and highly developed. Or, we could take advantage of the sharp antenna fieldwork supplies to explore practices of critique that are embedded in everyday struggles to survive and endure; or in what Raymond Williams (1977) called "structures of feeling" that embody the tensions of life as it is lived and may be broadly shared, even when they are barely enunciated. Some of Fassin's interlocutors have articulate critiques that translate quite easily into terms a broad public can recognize while for others, as he points out, critical insights are to easily dismissed as bizarre until a scholar "on the threshold of the cave" supplies context, interpretation, and analysis.

Middles: The figure of the ethnographer on the threshold is a kind of middle-(wo)man, a broker who mediates between two worlds of meaning. Fassin suggests that mediation to render critique intelligible is "helpful for action", but he does not elaborate on how it helps, or the kinds of action that could follow. From his account, it seems that his own critical work has been mainly useful for policy and for public information. These are important steps: no democratic debate can proceed until unfamiliar others are recognized as legitimate interlocutors who are competent to engage in democratic debate.

An important task for ethnographers is to investigate who else (besides themselves) does the work of mediation, or what Stuart Hall (1996) called articulation in its double sense: clarifying critical knowledge that is inchoate or emergent and formulating it within the lines of intelligibility that interlocutors (whether allies or adversaries) can grasp; and forging links between social forces so that critique can be amplified, collective positions formulated, and action ensue. Often, this mediating work is done by "organic intellectuals" (religious leaders, school teachers, movement activists, party cadre) whose positions enable them to straddle social, intellectual and spatial divides. Because - like critique mediation of this kind is broadly distributed, its potential to bring about world-making transformation is very much greater than the mediation ethnographers can provide. Hence ethnographers should attend

\footnotetext{
${ }^{1}$ https://en.wiktionary.org/wiki/\%CE\%BA\%CF\%81\%CE\%AF\%CE\%BD\%CF\%89
} 
to it: identify who is mediating what kinds of knowledge, and make critical discernments about whether or not to play a supporting role.

Ends: Fassin started his paper by arguing that Latour's worry that critique has been taken up by the wrong people for the wrong purposes is misplaced: people devise their own critiques regardless. A more important worry, which I share with Fassin, is the opposite one: that the kinds of critical practice intellectuals engage in will not expand "into society" but rather be "limited to academic circles". If, to paraphrase Marx, the point is not just to interpret the world, but also to change it, then ethnographers can't stop at co-producing knowledge or at mediation. We also need to co-produce forms of action that change the course of history.

No doubt many kinds of action, and many kinds of change, are possible: I'm not suggesting that one size fits all. But if we see our ethnographic work as a critical practice, it is important to reflect on the purpose of that practice. What are the ends we want it to serve? Taking the question of ends seriously may mean a different approach to the beginning: selecting research projects that offer a critical purchase on worldmaking processes, and considering the allies, interlocutors and adversaries we want to build into our research design.

Hall, Stuart

1996 On Postmodernism and Articulation: An Interview with Stuart Hall. In Stuart Hall: Critical Dialogues in Cultural Studies. L. Grossberg, D. Morley, and K.-H. Chen, eds. Pp. 131-150. London: Routledge.

Williams, Raymond

1977 Marxism and Literature. Oxford: Oxford University Press. 